possibility of distinguishing efficiency of nitrogen fixation per unit nodule tissue might become of considerable help for nutrition studies in legumes, under field and greenhouse conditions. Complete results will be published elsewhere.

This work has been supported by the Conselho Nacional de Pesquisas, Brazil, and by tho U.S. Agency for International Development. Thanks are due to A. F. Penteado for statistical advice and to R. Alvahydo for helpful discussions.

Instituto de Pesquisas e Expermentacáo

Agropeeuárias do Centro Sul, Campo (Grande, Guanabara, Brazil.

${ }^{1}$ Lange, R. T., and Parker, C. A., Nature, 186, 178 (1960).

" Pite, J. 8., Austral. J. Biol. Sei., 11, 366 (1958).

${ }^{3}$ Chen, H. K., and Thornton, H. G., Proc. Roy. Soc., B, 129, 208 (1940).

' Bowen, G, D., Qd. J. Agric. Sci., 16, 267 (1959).

${ }^{5}$ Döbereijer, J., Arruda, N. B., and Pentcado, A. F., Ninth Intern. Grassland Congr." (1965).

- Döbereiner, J., and Aronovich, S., Ninth Intern. Grassland Congr. (1965).

'Dobberciner, J., Flant and Soil (in the press).

${ }^{3}$ Andrew, C. S., and Norris, D. O., A Astral. J. Agric. Ties., 12, 44 (1961).

\section{Anisopus Larvae (Diptera) in Cases of Intes- tinal and Urino-genital Myiasis}

$\mathrm{Z}_{\mathrm{UMTPT}^{1}}{ }^{1}$ in his comprehensive work on myiasis in the old World includes Anisopus (Anisopodidae) under intestinal myiasis. James, writing on myiasis from the New World, also includes Anisopus (as Sylvicola) in the same category. Smart ${ }^{3}$ states that thore are rocords of Anisopus larvae in cases of intestinal and urino-genital myiasis. Many of the early toxt-books of medical ento. mology do not include the genus.

There appears to be only one published record of intestinal myiasis involving larvae of Anisopus fenestralis (Scop.): this is the one reported by Shrowsbury ${ }^{4}$. In this cuse a 3-yoar-old girl, after an attack of vomiting, developed a mild enteritis which lasted for some 2 weeks. On two separate occasions a single larva was found in her motions and in the third week of her illness two more larvae were found in her chamber-pot immediately after urination. There was no urethral or vaginal irrita. tion in this case, as would be expocted if larvae had been prosent in the urino-genital system, and it is therefore assumed that the larvae woro passed per anum. There appear to be no published records of urino-genital myiasis involving Anisopus, and Dr. Smurt informs us that his statement was based on an unpublished case which he dealt with when on the staff of the British Museum (Natural History).

Wo can now record a case of urino-genital myiasis involving larvae of Anisopus fenestralis brought to us by Dr. H. H. Johnston, of the Public Health Laboratory, Oxford, in 1962 .

The patient was a prognant woman, of reasonable intelligonco. Larvae had been passed in the urine for up to a month when she directed her private doctor's atten. tion to thom. He thon sent a urine sample to the Public Health Laboratory for investigation. The sample, which was brown in colour, contained about half a dozen larvao ono of which was sent to tho Hopo Department of Entomology, Oxford, for identification. This larva was dotormined by us as Anisopus fenestralis in the socond instar (10 $\mathrm{mm}$ long).

Of tho seventy or so species of Anisopodidae (= Rhyphidae) known, only Anisopus fenestralis has been accused of oausing myiasis. Keilin and Tato ${ }^{5}$ give a detailed description and figures of the third instar larva, which is 12-14 mm long. It may be that records of Anisopus have been overlooked, and for convenience the larva of A. fenestralis is illustrated here. The most important diagnostic oharacter of Anisopus is a shield-like thickening, lined by very large hypodermal colls, which surrounds the anus, the shape of this structure varying with the spocies.

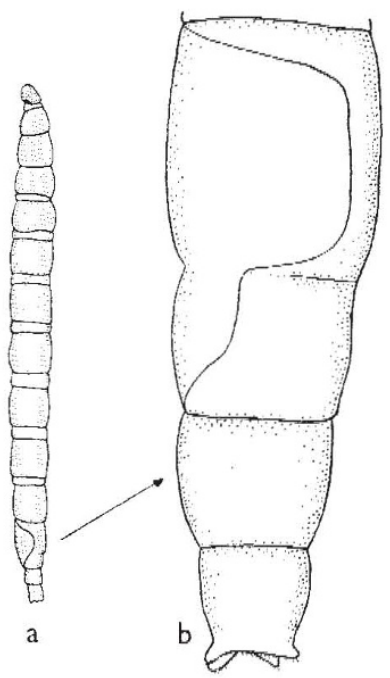
Fig. 1. $a$, Third instar larva of Anisopus fenestralis (L.); $b$, same showing

Shrewsbury ${ }^{4}$ suggested that with the intestinal myiasis case, the patient had swallowed eggs which hatched in the intestine. Zumpt ${ }^{1}$, after considering the possibility that the larvae were already in an advanced stage when swallowed or that eggs were deposited near the anus, Cavours Shrewsbury's view because of the small number of larvae recovered. Smart ${ }^{3}$ suggests that in these cases eggs may be laid directly in the pubic region.

Tho larvae of Anisopus have been recorded from various habilats such as slime flux exuding from tree wounds, decaying leaves in tree rot.holes, decaying roots of angelica and burdock, honeycombs, rotting potatoes, mouldy decaying cardbourd and sewage filter beds. Edwards ${ }^{B}$ records a remarkable case of Anisopus breeding in liver that had been in formalin for 7 years. The eggs are enclosed in a large gelatinous mass when laid and a gravid female will probably oviposit on any suitable moist surface. It is therefore probable that infection of tho urino-genital tract by larvae of Anisopus is purely fortuitous.

Department of Entomology,

K. G. V. Sмгтн

British Museum (Natural History)

$$
\text { London. }
$$

\section{E. TAYLOR}

Hope Department of Entomology, University Museum, Oxford.

${ }^{1}$ Zumpt, F., Myiasis in Man and Animals in the Old World (Butterworths, London, 1965).

${ }^{2}$ James, M. T., U.S. Dept. Agric. Misc. Publ.,1, No. 681.

smart, J., Insects of Medical Importance (1947), third ed. (British Museun (Natural History), London, 1956).

4 Shrewsbury, J. F. D., Brit. Med. J., i, 1043 (1930).

5 Kellin, D., and Tate, Y., Trans. Roy. Entomol. Soc., Lond, 90, 39 (1940).

- Edwards, F. W., Genera Insectorum, 190 (1928).

\section{Lichens with Bitunicate Asci}

THE division of the class Ascomycotes into the two sub-classes Ascomycetes and Loculoascomycetes in accordance with the ideas of Nannfeldt ${ }^{1}$ is now generally accepted. Characteristic of the sub-class Ascomycetes are the unitunicate ascus and true paraphyses, of the sub-class Loculoascomycetes the bitunicate ascus and paraphysoid filaments. Two British species belonging to genera the ascocarps of which were of unknown type are now found to belong to the Loculoascomycetes. They are Pyrenula nitida (Weig.) Ach. and Anthracothecium pyrenuloides (Mont.) Müll. Arg. These two species, typical of 